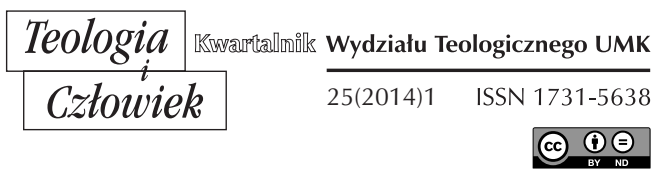

KS. MATEUSZ POTOCZNY*

KAMIEŃ ŚLĄSKI

\title{
RODZINY LITURGICZNE CHRZEŚCIJAŃSKIEGO WSCHODU - PANORAMA
}

DOI: http://dx.doi.org/10.12775/TiCz.2014.009

W środowiskach, w których liturgia rzymska wiedzie prym i niejako posiada monopol na bycie celebrowana, trudno dostrzec całe bogactwo i dziedzictwo liturgiczne Kościoła, wedle niektórych oddychającego nie dwoma, ale trzema płucami ${ }^{1}$. Na to bogactwo obok Kościołów Zachodu składa się cudowna i wciąż tajemnicza mozaika tradycji wschodnich. Taki stan rzeczy domaga się opracowań, które choćby w panoramiczny sposób przybliżą polskiemu czytelnikowi tę starożytną i wciąż za mało

* Mateusz Potoczny - dr Kościelnych Nauk Wschodnich w zakresie liturgii (PIO, Rzym), prezbiter diecezji opolskiej, birytualista, pracownik naukowo-badawczy w Instytucie Badań Nauczania Papieskiego w Kamieniu Śląskim.

${ }^{1}$ Prekursorem idei dwóch płuc Kościoła (katolicyzmu i ortodoksji) był rosyjski poeta Wiaczesław Iwanowicz Iwanow. Pojęcie to zaadaptował następnie Jan Paweł II, mówiąc o konieczności prowadzenia dialogu ekumenicznego z prawosławnym Wschodem. Jednak Sebastian Brock, najwybitniejszy dziś znawca Kościołów i tradycji syryjskich twierdzi, że Kościół oddycha trzema płucami: zachodnim (w przeważającej mierze łacińskim), wschodnim-prawosławnym i wschodnim-syryjskim. Zob. R. Bird, The Russian Prospero: The Creative Universe of Viacheslav Ivanov, London 2006, s. 39, 189; Jan Paweł II, Ut unum sint, nr 54; S. Brock, The Syriac Orient: a Third 'Lung' for the Church?, „Orientalia Cristiana Periodica” 71 (2005), s. 5-20. 
znaną rzeczywistość. Niniejsza prezentacja, będąca zarysem liturgicznego dziedzictwa chrześcijańskiego Wschodu, chce być przyczynkiem pobudzającym większe zainteresowanie Orientem.

W związku z wielością i złożonością Kościołów Wschodnich już na początku należy zaznaczyć, że prawidłowe zestawienie rodzin liturgicznych wymaga uprzedniej precyzacji istotnych pojęć, a następnie geograficznego umiejscowienia i historycznego usystematyzowania omawianych wspólnot, co będzie stanowić punkt wyjścia tegoż opracowania. Następnie zaprezentowane zostaną wschodnie rodziny liturgiczne wraz z wyrosłymi z nich tradycjami. Z oczywistych względów każda z nich zostanie omówiona bardzo ogólnie, jednakże ze zwróceniem uwagi na wyróżniające ją spośród innych cechy².

\section{GEOGRAFIA I TERMINOLOGIA}

W tradycyjnym pojęciu terminy „Wschód/Orient” wiążą się sensu stricto z podziałami Cesarstwa Rzymskiego dokonanymi przez cesarza Dioklecjana (284-305) ${ }^{3}$. W tym kluczu przez chrześcijański Wschód rozumie się więc tereny administracyjnie należące do pars orientalis Imperium oraz niektóre, położone poza jego granicami, a pozostające pod wpływem wywodzących się stamtąd wyznawców Chrystusa (perska Mezopotamia, Armenia, Gruzja, Etiopia czy Wybrzeże Malabarskie w Indiach); sam termin Kościoły Wschodnie precyzuje geograficzne ramy ich umiejscowienia. Jednak, jak zauważa Filippo Carcione, taka klasyfikacja, choć wciąż powszechna, może być jedynie punktem wyjścia w spojrzeniu na Kościoły Orientu. W rzeczywistości jest ona bowiem silnie zabarwiona ideologiczną europeizacją, widzącą w Rzymie centrum świata, religii i polityki. Według autora słuszniejsze jest określanie wywodzących się z Bliskiego Wschodu Kościołów ich jednostkowymi nazwami własnymi ${ }^{4}$. Wydaje się jednak, że ze względu na powszechność i geograficzną ja-

${ }^{2}$ Należy dodać, że owe cechy wyróżniające odnoszą się do tradycji jako takiej, nie precyzując zmian, jakie przeniknęły do poszczególnych liturgii pod wpływem unii z Rzymem zawieranych przez poszczególne wspólnoty.

${ }^{3}$ W jednym z podziałów dokonanych przez Dioklecjana na Orient składały się następujące prowincje: Cylicja, Cypr, Mezopotamia, Syria, Palestyna, Arabia, Egipt i Libia. Por. V. Poggi, Panorama storico delle Chiese cristiane in Asia e in Africa, Bologna 2005, s. 11.

${ }^{4}$ F. Carciocne, Le antiche chiese orientali, "Credere oggi" 3/147 (2005), s. 9-14. 
sność, zastosowanie terminu „Kościoły Wschodnie” jest usprawiedliwione. Zbyt pochopne jego unikanie mogłoby wprowadzić niepotrzebny chaos i dezorientację metodologiczną. Ponadto pojęcie to jest dziś akceptowane nie tylko na Zachodzie, ale także we wspólnotach będących podmiotami rzeczonego Wschodu.

Przywołany F. Carcione zwraca uwagę na jeszcze inną osobliwość: według niego mimo różnic i ogromnych podziałów, jakie na przestrzeni dziejów narosły między Kościołami Rzymu i Konstantynopola, przez wieki istniała między nimi przedziwna zgodność co do nazywania „wschodnim" jedynie tego, co tyczyło się tradycji bizantyjskiej. Tendencję tę autor słusznie nazywa redukcją starożytnego chrześcijaństwa bliskowschodniego, która wciąż jeszcze zdaje się pokutować w mentalności rzymsko-bizantyjskiej ${ }^{5}$.

Zatem chrześcijaństwo narodziło się na Wschodzie. Pierwsi uczniowie Chrystusa, wychodząc z Jerozolimy, kierowali swoją działalność misyjną zarówno na świat orientalny, jak i hellenistyczny ${ }^{6}$. Nowa religia, zwłaszcza z powodu prześladowań, szybko się rozprzestrzeniała, tworząc w większych miastach swoje pierwsze ośrodki ${ }^{7}$. W przeciągu pierwszych piętnastu lat prawdziwym centrum chrześcijańskiej ekspansji była Syria - zarówno grecka, ze stolicą w Antiochii, jak i aramejska, ze stolica w Damaszku, o czym informują nas przekazy biblijne (por. Dz 9; 11; 22; 26). Inne znaczące ośrodki chrześcijaństwa w tym okresie to północno-

${ }^{5}$ Por. Tamże, s. 10. Ciekawostką może być definicja zawarta w wydanej w pierwszej połowie XX w. Encyklopedii religii i etyki. Zamieszczone tam hasło „Kościół Wschodni” („Eastern Church”), występując w liczbie pojedynczej, odnosi tę nazwę w pierwszej kolejności do prawosławia, inne tradycje zaś, choć wspomniane, zdają się zajmować jedynie pozycję drugorzędną. Zob. J. Hasting (red.), Encyclopedia of Religion and Ethics, t. 5, New York 1920, s. 134.

${ }^{6}$ Głównie na podstawie pism św. Pawła dokonuje się czasem błędnej redukcji początków chrześcijaństwa, ograniczając je do świata wpływów greckich. Jak zauważa Jean Daniélou, Apostoł Narodów, będąc Grekiem, kierował swoje pisma do Greków. Nie był przy tym zainteresowany chrześcijaństwem z kręgu języka aramejskiego. Tymczasem środowisko helleńskie to tylko jedna część historii pierwotnego Kościoła, niezwykle istotna, ale nie jedyna. Analizując wczesne chrześcijaństwo, nie należy zapominać, że w znacznej mierze przynależało ono do kręgu semickiej kultury syryjskiej oraz bardzo wcześnie także do hebrajsko-hellenistycznej kultury egipskiej. Sam zaś Kościół pierwotny przez pewien czas pozostawał w ścisłym związku ze środowiskiem żydowskim. Por. J. Daniélou, H. I. Marrou, Historia Kościoła I. Od początków do roku 600, Warszawa 1984, s. 21.

7 Por. P. Jaskóła, Wyznania chrześcijańskie bez jedności z Rzymem, Opole 2008, s. 7. 
afrykańska Aleksandria oraz syryjskie Edessa i Nisibis. Zupełnie nowy rozdział w klasyfikacji Kościołów chrześcijańskiego Orientu rozpoczął się wraz z utworzeniem patriarchatu w Konstantynopolu i przyznaniem na drugim soborze powszechnym (Konstantynopol, 381) biskupowi tegoż miasta najwyższego po papieżu miejsca w Kościele [kan. 3], co następnie utwierdzono postanowieniami Soboru Chalcedońskiego (451), który w kan. 28. biskupa Nowego Rzymu zrównał z papieżem8. Od tamtego czasu nowa stolica Imperium i wytworzona w niej tradycja zaczęła niezasłużenie pretendować do bycia środkiem ciężkości wschodniego chrześcijaństwa. Zdawano się zapominać, że w czasie gdy Bizancjum dalekie było jeszcze od przyznania mu statusu "Nowego Rzymu” i stanowiło jedynie małą wspólnotę całkowicie zależną od metropolity Heraklei, Antiochia i Aleksandria żyły już na sposób patriarchalny, wyprzedzając de facto decyzje późniejszych soborów ${ }^{9}$.

W tym miejscu doprecyzowania wymaga jeszcze pojęcie "rytu”. $\mathrm{W}$ zachodnim (potocznym) rozumieniu oraz w pobożności ludowej zakres znaczeniowy tego terminu często ogranicza się do określenia pewnych czynności liturgicznych lub kultycznych, takich jak sprawowanie sakramentów czy sakramentaliów. Tymczasem w znaczeniu szerszym, powszechnym we wschodnich ujęciach zagadnienia, ryt jest zazwyczaj utożsamiany z obrządkiem i odnosi się do całego dziedzictwa liturgicznego, teologicznego, duchowego i dyscyplinarnego danej wspólnoty, jej odrębności kulturowych oraz historycznych okoliczności, które wyrażają się w sposobie życia wiary, jaki właściwy jest każdemu Kościołowi sui iuris (por. KKKW 28,1). Jednocześnie ryt/obrządek jako bezcenne dziedzictwo i element wyróżniający Kościoły nie jest ich synonimem, gdyż tylko wspólnota z jej widzialną głową jest właściwą osobą prawną ${ }^{10}$. Innymi słowy: rozumiejąc czym jest liturgia Kościoła i kim jest uczestniczący w niej człowiek, który rozwija się i udoskonala w konkretnym czasie i miejscu, w takiej, a nie innej grupie ludzi powiązanych tradycją

${ }^{8}$ Por. G. Ostrogorski, Dzieje Bizancjum, Warszawa 2007, s. 98.

${ }^{9}$ Przypomnijmy, że pentarchię usankcjonował dopiero Sobór Chalcedoński (451 r.), który do istniejących już wcześniej stolic patriarchalnych (Antiochii, Aleksandrii, Rzymu i Konstantynopola) dodał także Jerozolimę. Por. F. Carciocne, dz. cyt., s. 11; M. Nin, Storia delle liturgie orientali, w: A. J. Chupungco (red.), Scientia liturgica. Manuale di Liturgia, t. 1, Casale Monferrato 1998, s. 131.

${ }^{10}$ Por. D. Salachas, „Rito e riti”, w: E. G. Farrugia (red.), Dizionario enciclopedico dell'Oriente cristiano, Roma 2000, s. 634-635; S. Rosso, La celebrazione della storia della salvezza nel rito bizantino, Cittŕ del Vaticano 2010, s. 19-20. 
oraz dziedzictwem kulturowym i historyczno-geograficznym, można pojąć zakres znaczeniowy rytu/obrządku, tak jak jest on powszechnie rozumiany na Wschodzie ${ }^{11}$.

\section{ORIENTALNY PLURIFORMIZM LITURGICZNY}

Liturgia, będąca uobecnieniem zbawczego dzieła Chrystusa, kontynuowanego $\mathrm{w}$ dziejach na sposób sakramentalny, powinna być i jest sercem całego Kościoła oraz językiem, poprzez który ów Kościół Chrystusowy się wyraża ${ }^{12}$. Spełniając taką funkcję, jest również szczytem działalności Kościoła i źródłem jego mocy (por. KL 10). Na Zachodzie bywa ona rozumiana dość szeroko, zawierając w sobie wszystkie formy kultu sprawowanego przez Kościół; na Wschodzie oznacza głównie sprawowanie Eucharystii ${ }^{13}$. Bez względu jednak na różnice $\mathrm{w}$ ścisłym rozumieniu samego jej pojęcia, dla każdego chrześcijanina liturgia jest rzeczywistościa, poprzez którą wchodzi on $\mathrm{w}$ relację z Chrystusem i stanowi przedziwną z Nim komunię ${ }^{14}$. We wschodnich wspólnotach liturgia jest też głównym miejscem refleksji teologicznej, pierwszym i najbardziej widzialnym aspektem ich życia, a momenty wielkich przemian świata, w którym rozwijały się Kościoły, w niej właśnie zostawiły swój ślad, czyniąc zeń uprzywilejowane świadectwo wiernie przekazujące istotne wartości ${ }^{15}$.

Choć źródłem i głównym protagonistą liturgii jest jeden i niepodzielny Chrystus, jedną z charakterystycznych jej cech, szczególnie wyróżniającą się na chrześcijańskim Wschodzie, jest wielość form wyrazu. Należy zauważyć, że zarówno teologia jak i liturgia chrześcijańska od zarania wpisane były tam w kontekst, w którym wielkie znaczenie odgrywały różnice ${ }^{16}$. Ów pluriformizm wynikał już z samej specyfiki Wschodu. Jak czytamy w dokumencie Orientale lumen: „Chrześcijański Wschód od samych początków jawi się jako wewnętrznie zróżnicowany, zdolny przyjąć charakterystyczne rysy każdej poszczególnej kultury i zachowujący

${ }^{11}$ Por. I. H. Dalmais, Liturgies d'Orient. Rites et symboles, Paris 1980, s. 35.

12 Por. R. Taft, "La liturgia nella vita della Chiesa”, w: tenże, A partire dalla liturgia. Perché è la liturgia che fa la Chiesa, Roma 2004, s. 46.

${ }^{13}$ Por. J. M. Czerski, Liturgie Kościołów Wschodnich, Opole 2009, s. 19.

${ }^{14}$ Por. I.H. Dalmais, Liturgies, s. 35.

15 Por. S. Rosso, dz. cyt., s. 38.

${ }^{16}$ Por. V. Poggi, dz. cyt., 7. 
najwyższy szacunek dla każdej wspólnoty lokalnej" (OL 5). Oczywiście różnice i autonomia w kwestiach wiary nie dotyczyły spraw najbardziej fundamentalnych. Zarówno wspólnoty Wschodu, jak i Zachodu łączyła ta sama wiara w Jezusa Chrystusa i Jego zmartwychwstanie oraz w Trójcę Świętą, ta sama tradycja biblijna, świadomość konieczności szafarstwa sakramentów (w szczególności chrztu i Eucharystii), a także wiara w życie wieczne. Jednakże $\mathrm{w}$ innych aspektach do głosu dochodziło wiele różnic, które sprowokowały pojawienie się odmiennych denominacji chrześcijan ${ }^{17}$.

W omawianych Kościołach liturgia nigdy nie była czymś narzuconym z zewnątrz: zachowując swoje istotne elementy, akceptowała i przyjmowała różne formy wyrazu odpowiednie zarówno dla kultury, jak i dla teologii sprawujących ją ludów. Można zaryzykować stwierdzenie, że w tej liturgiczno-eklezjalnej różnorodności jeszcze pełniej wyraża się katolickość Kościoła Chrystusowego, która znajduje swoje uzewnętrznienie właśnie w zwyczajach właściwych konkretnym tradycjom lokalnym ${ }^{18}$.

Poszczególne liturgie Kościołów Wschodnich od początku różniły się m.in. odmiennym rozłożeniem akcentów teologicznych, przyjętymi formami liturgicznymi, rolą ludu i duchowieństwa oraz architekturą sakralnąa ${ }^{19}$. Wraz z kształtowaniem się ośrodków teologicznych i katechetycznych powstały na Wschodzie centra stanowiące mateczniki tradycji liturgicznych. Choć środowiska Jerozolimy, Antiochii, Aleksandrii, Edessy, Nisibis i Konstantynopola wywarły znaczący wpływ na rozwój liturgicznych tradycji Wschodu, należy przyjąć, że wszystkie obrządki wschodnie mają źródło w dwóch pierwszych z nich. Zarówno syryjska Antiochia, jak i egipska Aleksandria od najdawniejszych czasów nadawały kierunki rozwijającej się teologii i liturgii ${ }^{20}$. To przecież w Antiochii wykształciła się mistrzowska szkoła egzegetyczna, oparta na metodzie historyczno-literalnej. $\mathrm{W}$ debatach teologicznych środowisko tego miasta jawiło się jako przywiązane do dziedzictwa starotestamentalnego, z silnym akcentowaniem jedyności Boga ${ }^{21}$. Z kolei w leżącej $w$ delcie Nilu

17 Por. P. D. Day, Eatsern Christian Liturgies. The Armenian, Coptic, Ethiopian and Syrian Rites, Shannon 1972, s. 2. Pełną prezentację Kościołów Wschodnich, katolickich, jak i niebędących w jedności z Rzymem, można znaleźć m.in. w: R. G. Roberson, Chrześcijańskie Kościoty Wschodnie, Kraków 2005.

18 Por. I. H. Dalmais, Liturgies, s. 31-32.

19 Tamże.

${ }^{20}$ Por. I. H. Dalmais, The Eastern Liturgical Families, w: A. G. Martimort (red.), The Church at Prayer, t. 1, Collegeville 1986, s. 28.

${ }^{21}$ Por. M. Banaszak, Historia Kościoła, t. 1, Warszawa 1986, s. 29; H. Langkammer, 
Aleksandrii zostały zorganizowane pierwsze studia teologiczne, które odegrały pierwszoplanową rolę $\mathrm{w}$ dziedzinie formowania katolickiej doktryny trynitarnej i chrystologicznej. Aleksandryjska egzegeza cechowała się finezją alegoryczną, w debacie teologicznej zaś środowisko było otwarte na filozofię grecką ${ }^{22}$. Obecni w tych miastach wyznawcy Chrystusa, obok specyficznej teologii, dość szybko wykształcili charakterystyczne liturgie, dające początek liturgicznym rodzinom: syro-antiocheńskiej i aleksandryjskiej ${ }^{23}$. Należy zauważyć, że wywodzące się z nich poszczególne tradycje liturgiczne nie były wynikiem bezpośredniej emanacji, lecz owocem procesu rozwoju, w którym istotnymi elementami były kombinacje, zmiany i zapożyczenia ${ }^{24}$. Manel Nin zauważa, że w kształtowaniu się poszczególnych liturgii można wyróżnić dwie fazy: epokę archaiczną (I-IV w.) i epokę konsolidacji, cechującą się wzajemnym oddalaniem się Kościołów i liturgii (od V w.) $)^{25}$.

\section{LITURGICZNA RODZINA SYRO-ANTIOCHEŃSKA}

W środowisku antiocheńskim zrodziła się forma liturgii będąca swoistą mieszanką elementów semickich i greckich. Dała ona początek dwom tradycjom: zachodniosyryjskiej, która ukształtowała się pod wpływem helleńskiej Antiochii, i wschodniosyryjskiej, przywiązanej bardziej do korzeni sięgających kultury semickiej ${ }^{26}$. Najstarsze świadectwa liturgiczne zaliczane do tej rodziny znajdujemy w Didaché, Tradycji Apostolskiej, w niektórych anaforach (np. Liturgia Jakuba brata Pańskiego, Liturgia Addaja i Mariego), a także w homiliach i katechezach Ojców Kościoła. Głównymi językami liturgicznymi były tu grecki i dialekt aramejskiego zwany syryjskim. Pierwszy z nich przeważał na terenach greckich, natomiast językiem syryjskim (zarówno w formie zachodniej, jak i wschodniej)

Antiocheńska szkoła egzegetyczna, w: F. Gryglewicz - in. (red.), Encyklopedia katolicka, t. 1, Lublin 1985, kol. 647; F. Carciocne, dz. cyt., s. 11. Dla poszerzenia tematu szkoły antiocheńskiej i jej wkładu w dziedzictwo teologiczne zob. D. S. Wallace-Hadrill, Christian Antioch. A study of early Christian thought in the East, Cambridge 1982.

${ }^{22}$ Por. R. Gostkowski, Z. Kiss, Aleksandria, w: F. Gryglewicz - in. (red.), dz. cyt., kol. 341; B. Kumor, Patriarchaty Aleksandrii, w: tamże, kol. 342; F. Carciocne, dz. cyt., s. 11.

${ }^{23}$ Por. M. Nin, Storia, s. 132.

${ }^{24}$ Por. P. D. Day, dz. cyt., s. 1.

25 Por. M. Nin, Storia, s. 131-135.

${ }^{26}$ Por. Tamże; I. H. Dalmais, The Eastern, s. 28-29. 
posługiwano się w Kościołach Persji i Mezopotamii oraz w niektórych środowiskach klasztornych rejonu antiocheńskiego ${ }^{27}$.

\subsection{TRADYCJA WSCHODNIOSYRYJSKA}

Liturgie należące do tej tradycji ukształtowały się na terenach leżących poza wschodnimi rubieżami Imperium Rzymskiego, między rzekami Tygrys i Eufrat, na terenach Perskiego Imperium Sassanidów, a następnie Kalifatu Abbasydów. Już samo położenie sprawiło, że zrodzony tam Kościół nazywany był po prostu Kościołem Wschodu. W prowincjach tych hellenizacja była słaba, a ludzie mówili dialektami języka aramejskiego. Te okoliczności połączone z dużą diasporą żydowską pozostałą po niewoli babilońskiej sprawiły, że chrześcijaństwo zachowało tam liczne elementy semickie. Od strony teologicznej Kościół ów przyjął credo nicejskie, jednak później wykształcił własną koncepcję dwóch natur w Chrystusie oraz naukę dotyczącą Matki Bożej (Theotókos), nie przyjmując przy tym uchwał Soboru Efeskiego (431) ${ }^{28}$.

Choć teologicznie wywodzący się z kręgu wpływów antiocheńskich, dość szybko główne autonomiczne centra liturgiczne Kościoła skoncentrowały się wokół wspomnianych już miast - Edessy i Nisibis - a język wschodniosyryjski stał się ich językiem liturgicznym oraz

${ }^{27}$ Por. M. Nin, Storia, s. 132. Ze względu na specyfikę liturgii wschodniosyryjskiej niektórzy autorzy nie zaliczają jej do grupy syro-antiocheńskiej, nazywając ją samą w sobie odrębną rodziną liturgiczną (zob. P. D. Day, dz. cyt., s. 5-6; X. Koodapuzha, Oriental Churches an Introduction, Kottayam 1996, s. 108-111). Wydaje się jednak, że taki podział nie jest uzasadniony z punktu widzenia historycznego. Region Tygrysu i Eufratu był bowiem głównie antiocheńskim polem działalności ewangelizacyjnej, a sama liturgia w jej głównych zrębach cechuje się wieloma podobieństwami do liturgii syryjskiej zachodniiej.

${ }^{28}$ Ze względu na to, że Kościół nie przyjął uchwał Soboru Efeskiego (431 r.) potępiających Nestoriusza, dość często bywa on nazywany Kościołem Nestoriańskim. Jednak z punktu widzenia historyczno-teologicznego nazwa ta okazała się nieadekwatna; sam zaś Kościół stał się niezależnym jeszcze przed kontrowersją nestoriańską, w roku 410. Choć sam Nestoriusz jest czczony w Kościele jako święty, głównym doktorem Asyryjczyków jest Teodor z Mopsuestii. Por. E. G. Farrugia, Nostorianesimo, w: tenże (red.), dz. cyt., s. 522-523. Warto dodać, że po przeniesieniu stolicy do założonego po 762 r. Bagdadu, miasto to stało się także stolicą patriarchatu. Dla pogłębienia tematyki zob. także: A. S. Atiya, A History of Eastern Christianity, London 1968, s. 239-302; H. Denzinger, Ritus Orientalium, Graz 1961, s. 3 (wraz z przypisem 2.); P. Jaskóła, dz. cyt., s. 9-13; I. H. Dalmais, Liturgies, s. 46. 
spoiwem kulturowym. W początkach IV w. Kościół otrzymał konkretną strukturę zorganizowaną wokół biskupa (później patriarchy) perskiej stolicy, Seleucji-Ktezyfonu, a w średniowieczu był najprężniej rozwijającym się Kościołem w Azji. Dzięki jego misjonarskiej aktywności rozszerzył się po Tybet, Chiny, Mongolię i Indie. W XIV w. Kościół w całej Azji posiadał około 20 metropolii i 200 biskupstw $^{29}$.

W ewolucji liturgicznej Kościoła Wschodu możemy wyróżnić trzy etapy, związane z osobami katolikosów-patriarchów. Pierwszym była reforma dokonana przez Isho'yahba III (650-658), jednocząca różne obrządki Kościoła Wschodu; dzięki niej dokonano m.in. kodyfikacji brewiarza. Drugi etap stanowiła reforma Eliasza II (1176-1190), wzbogacająca dzieło dokonane pięć wieków wcześniej. Trzecia faza ewolucji wiązała się z Yehballahem II (1176-1190), który zgrupował tzw. Gazza, tj. skarbce hymnów liturgicznych ${ }^{30}$.

Jeśli chodzi o teksty liturgiczne, to - jak zauważa Irénéé-Henri Dalmais - do czasów współczesnych zachowały się głównie ich późne, średniowieczne wersje. Jednakże przetrwałe komentarze - głównie Teodora z Mopsuestii (†428), Narsaja z Edessy (V w.), Gabriela Qatraia (VII w.) i Pseudo-Jerzego z Arbela (IX-X w.) - ukazują całe piękno i bogactwo tej tradycji ${ }^{31}$. Najpopularniejsza tu Anafora Addaja i Mariego, zwana czasem Anaforą Apostołów, sięga swymi korzeniami III w. i jest zbliżona $\mathrm{w}$ formie do żydowskiego błogosławieństwa berakah ${ }^{32}$. Dwie

${ }^{29}$ Por. X. Koodapuzha, dz. cyt., s. 109. Philip Jenkins $\mathrm{w}$ jednej z publikacji poświęconych m.in. omawianemu Kościołowi zawarł bardzo ciekawą uwagę: „Zanim św. Benedykt założył pierwszy klasztor, przed czasami brytyjskiego króla Artura, nestoriańskie biskupstwa istniały w Nishapur i Tus w Chorasanie, w północnowschodniej Persji i w Rai. Zanim Anglia otrzymała pierwszego biskupa Canterbury - prawdopodobnie zanim Canterbury miało jakikolwiek chrześcijański kościół - Kościół Nestoriański miał już metropolitów w Merw i Herat, w dzisiejszym Turkmenistanie i Afganistanie, a kościoły działały na Sri Lance i Wybrzeżu Malabarskim. Zanim król Wacław rządził chrześcijańskimi Czechami, zanim Polska stała się katolicka, nestoriańskie biskupstwa w Bucharze, Samarkandzie i Patnie miały już status metropolii. Nasza powszechna mapa mentalna historii chrześcijaństwa pomija tysiąc lat tej historii i kilka milionów mil kwadratowych terenu. (...) Nie możemy zrozumieć historii chrześcijaństwa bez Azji - albo, w rzeczy samej, historii Azji bez chrześcijaństwa". P. Jenkins, The Lost History of Christianity, Oxford 2008, s. 11. Zob. także: M. Nicolini-Zani, La via radiosa per l'oriente, Magnano 2006.

${ }^{30}$ Por. I. H. Dalmais, The Eastern, s. 29; R. G. Roberson, dz. cyt., s. 15.

31 Por. M. Nin, Storia, s. 137-138.

${ }^{32}$ Por. R. Cabié, The Eucharist, in: A. G. Martimort, (red.), The Church at Prayer, t. 2, Collegeville 1987, s. 29-34; I. H. Dalmais, The Eastern..., s. 29-30. 
pozostałe anafory używane do dziś w Kościele Wschodu przypisywane są Teodorowi z Mopsuestii i Nestoriuszowi († ok.450) ${ }^{33}$.

Wśród pozamszalnych celebracji sakramentalnych jedynie chrzest i sakrament święceń uzyskały rozwiniętą i dobrze opracowaną formę ; pozostałe sakramenty - żeby użyć sformułowania jakim posłużył się I. H. Dalmais - wciąż jeszcze pozostają w stanie embrionalnym ${ }^{34}$. $Z$ resztą gdy idzie o kwestie sakramentów to przyjmuje się, że Kościół Wschodu uznaje ich siedem, jednak nie są one jasno sprecyzowane. Co do czterech nie ma wątpliwości: chrzest, Eucharystia, sakrament święceń i małżeństwo. Jednak pozostałe trzy $\mathrm{w}$ opiniach niektórych oscylują wokół błogosławieństwa mnichów, oficjum za zmarłych, oleju namaszczenia, absolucji, świętego zaczynu, znaku krzyża oraz dedykacji kościoła ${ }^{35}$.

Ważnym elementem celebracji wschodniosyryjskich od najdawniejszych czasów była poezja, której najsłynniejszym twórcą był św. Efrem z Nisibis († 373). Jego teksty do dziś są głównym źródłem poznania liturgii owego $\mathrm{Czasu}^{36}$.

Za Azizem Atiyą warto zwrócić uwagę na kilka charakterystycznych cech omawianej tradycji: celebracja eucharystyczna nie jest tu koniecznie związana z liturgią niedzielną; każdorazowe przyjęcie komunii św. wymaga od wiernych postu od północy, zaś celebrans i diakon winni rozpocząć swoje modlitwy w wigilię wyznaczonego dnia i kontynuować je o poranku dnia następnego, aż do chwili rozpoczęcia celebracji sakramentalnej; spowiedź nie jest wymagana do pełnego uczestnictwa w Eucharystii; rok liturgiczny rozpoczyna się pierwszego grudnia i dzieli się na dziewięć okresów; używany jest kalendarz juliański (w obliczaniu miesięcy), zaś system liczenia lat zaczerpnięty jest z tzw. ery Seleucydów ${ }^{37}$.

Do wschodniosyryjskiej tradycji liturgicznej należą: Asyryjski Kościół Wschodu, jego będący w jedności z Rzymem odpowiednik - Kościół Chaldejski i Kościół Syro-Malabarski.

${ }^{33}$ Por. S. Brock, A Brief Outline of Syriac Literature, Kottayam 2009, s. 109; F. E. Brightman, The Anaaphora of Theodore, "Journal of Theological Studies" 31 (1930), 160-164; A. S. Atiya, dz. cyt, 295.

${ }^{34}$ Por. I. H. Dalmais, The Eastern, s. 30.

${ }^{35}$ Por. A. S. Atiya, dz. cyt., 296.

${ }^{36}$ Por. I. H. Dalmais, Liturgies, s. 46-47.

${ }^{37}$ Por. A. Atiya, dz. cyt., s. 295. 


\subsection{TRADYCJA ZACHODNIOSYRYJSKA}

Drugą tradycją należącą do liturgicznej rodziny syro-antiocheńskiej jest tradycja zachodniosyryjska, silnie związana z leżącymi $\mathrm{w}$ granicach Cesarstwa Rzymskiego okolicami Antiochii. Najstarsza liturgia wywodząca się z tego środowiska przekazana została w Didascalia Apostolorum $(\text { III w. })^{38}$. Z dziedzictwa tej tradycji zrodziły się trzy odrębne ryty: syro-antiocheński, bizantyjski i ormiański (od pierwszego odróżnia się czasem liturgię maronitów, zaś drugi i trzeci często bywają ujmowane jako odrębne rodziny liturgiczne, jednak nie ulega wątpliwości, że środowisko antiocheńskie wywarło na nie duży wpływ) ${ }^{39}$.

\subsubsection{LITURGIA SYRO-ANTIOCHEŃSKA}

Początkowo w Kościołach tradycji zachodniosyryjskiej językiem liturgicznym była greka. Po ogłoszeniu przez Kościół jakobicki ${ }^{40}$ autonomiczności, do liturgii stopniowo zaczął wchodzić język syryjski (w jego zachodniej wersji zapisu i wymowy), a z czasem obrzędy wzbogacono o syryjską poezję przypisywaną św. Efremowi i Jakubowi z Sarug $(+521)^{41}$. Syro-antiocheńska tradycja liturgiczna cechowała się wielką różnorodnością. Niemal każdy klasztor i każda diecezja posiadała własne księgi liturgiczne oraz odrębne praktyki. Dla uzasadnienia takiego stanu rzeczy Baby Varghese przywołuje opinię jednego z najwybitniejszych pisarzy i liturgistów tego Kościoła, Dionizego Bar Salibi (†1171):

${ }^{38}$ Por. I. H. Dalmais, Liturgies, s. 48.

39 Por. I. H. Dalmais, The Eastern, s. 31-32.

40 Nazywany czasem "monofizyckim” ze względu na odrzucenie sformułowań Soboru Chalcedońskiego (451) dotyczących dwóch natur w Chrystusie. Termin „Kościół jakobicki" wywodzi się od imienia Jakuba Baradeusza (542/3-578), potajemnie wyświęconego na biskupa Edessy. Jako przeciwnik Chalcedonu wizytował prześladowane przez cesarzy Kościoły monofizyckie, ożywiając ich życie religijne i potajemne wyświęcając biskupów. Dla niepoznaki ubierał się w łachmany, stąd właśnie przylgnął do

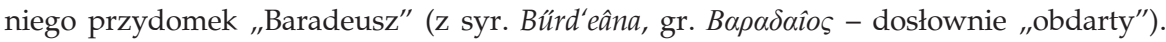
C. Capizzi, R. Lavenant, Giacobbe (Giacomo) Baradeo o Baradai, w: E. G. Farrugia (red.), dz. cyt., s. 339. Por. G. O'Collins, E. G. Farrugia, Leksykon pojęć teologicznych i kościelnych, Kraków 2002, s. 328-329.

${ }^{41}$ Por. I. H. Dalmais, The Eastern, s. 32. 
Fakt, że ludzie każdego kraju modlą się inaczej i mają coś, co odróżnia ich od reszty, idzie na ich korzyść, po pierwsze dlatego, że wskazuje na bogactwo ich pobożności i duchowej żywotności, i po drugie dlatego, że jest to znakiem niemożności pojęcia Boga, który pragnie być uwielbiony na różne sposoby, w różnych krajach i różnych miastach ${ }^{42}$.

W tym kluczu należy rozpatrywać kwestię długiego braku precyzacji istotnych formuł liturgicznych oraz otwarcia na nowe kompozycje hymnograficzne. Dodajmy, że sama liturgia, począwszy od VI w. zaczęła adaptować niektóre praktyki Kościoła Jerozolimskiego, a z czasem ubogaciła się także wpływami bizantyjskimi. Definitywnej jej kodyfikacji dokonano w XII w., głównie za sprawą cytowanego Dionizego Bar Salibi i patriarchy Michała Wielkiego (†1199). W następnych stuleciach język syryjski, pozostając głównym językiem liturgicznym, zaczął być zastępowany powszechnie używanym arabskim ${ }^{43}$. Niektórzy badacze, dostrzegając wspólne elementy liturgii syro-antiocheńskiej z liturgią wschodniosyryjska, są zdania, że liturgia zachodniosyryjska w jej dzisiejszej formie jest mezopotamską wersją tradycji antiocheńskiej ${ }^{44}$.

Najbardziej uroczystą modlitwą eucharystyczną jest tu Anafora św. Jakuba, ponadto znane są jeszcze 72 inne, dla których ta pierwsza była prototypem. Sam ryt cechuje się wielością tekstów poetyckich oraz gestów (szczególnie okadzeń i związanych z nimi tzw. Sedr ${ }^{45}$ ). Eucharystia odprawiana jest tylko w niedziele, dni świąteczne i okazjonalnie w dni powszednie. W brewiarzu tradycja zachowała zwyczajowe godziny od jutrzni do komplety, kalendarz liturgiczny zaś opiera się na systemie juliańskim; uznaje się siedem sakramentów tożsamych z sakramentami Kościoła łacińskiego ${ }^{46}$.

Osobny fenomen w tej tradycji prezentuje liturgia maronicka. W przeciwieństwie do jakobitów wierni zgromadzeni wokół klasztorów w górach Libanu przyjęli uchwały Chalcedonu. W ciągu VI w. utworzyli niezależny Kościół, silnie związany z Rzymem, co z kolei sprawiło, że

${ }^{42}$ A. Mingana (red.), A Treatise of Bar Salibi against the Melchites, t. 1, Cambridge 1927, s. 34. Por. B. Varghese, West Syrian Liturgical Theology, Aldershot 2004, s. 2-3.

${ }^{43}$ Por. I. H. Dalmais, Liturgies, s. 48-50; tenże, The Eastern, s. 32.

${ }^{44}$ Por. B. Varghese, dz. cyt., s. 2.

45 Sedro to tematyczna modlitwa błagalna odmawiana w czasie złożenia ofiary kadziła, czasem podzielona na wersy według akrostychu alfabetycznego. Zob. J. P. Deschler, Word and Meaning, Kottayam 2012, s. 254.

${ }^{46}$ Por. A. Atiya, dz. cyt., s. 224. 
Kościół maronicki, jak żaden inny, uległ szerokiej latynizacji (głównie w XVI-XVII w.), a jego liturgia jest dziś mieszanką syryjskiego Orientu i rzymskiego Zachodu. Widać to chociażby w celebracjach sakramentalnych: choć obrzęd małżeństwa odprawiany jest zgodnie z tradycją syryjską, posiada rzymskie dodatki; przy chrzcie dopuszcza się łacińską formę jego udzielania oraz na wzór Zachodu nie udziela się komunii św. chrzczonym dzieciom; od 1606 roku zaadaptowano kalendarz gregoriański, a z tradycji łacińskiej przejęto również niektóre święta (np. Uroczystość Najświętszego Ciała i Krwi Chrystusa) ${ }^{47}$. Oryginalną liturgię maronicką cechuje również wiele elementów charakterystycznych dla celebracji monastycznych. Ponadto można w niej odnaleźć starożytne elementy wskazujące na jej pokrewieństwo z wschodniosyryjską siostrą (np. maronicka Anafora św. Piotra jest zbliżona do Anafory Addaja i Mariego $)^{48}$.

Liturgia syro-antiocheńska celebrowana jest przez Syryjski Kościół Ortodoksyjny, Kościół maronicki (ze wspomnianymi zmianami), Malankarski Ortodoksyjny Kościół Syryjski, Syryjski Kościół Katolicki, Syro-Malankarski Kościół Katolicki, Niezależny Syryjski Kościół Malabaru, Syro-Malankarski Kościół Mar Thoma oraz Kościół Ewangelicki Świętego Tomasza ${ }^{49}$.

\subsubsection{LITURGIE BIZANTYJSKA I ORMIAŃSKA}

Tradycja bizantyjska jest bodaj najlepiej znaną i opracowaną ze wszystkich tradycji wschodnich. Z całą pewnością wiąże się to z faktem szczególnego wyniesienia Bizancjum do godności patriarchatu i Nowego Rzymu. Nie bez znaczenia jest też fakt, że Kościoły bizantyjskie stanowią dziś przynajmniej $4 / 5$ całego chrześcijaństwa wschodniego ${ }^{50}$.

Teologicznie oparty na nauce siedmiu pierwszych soborów powszechnych ryt bizantyjski ukształtował się między VI i IX w. wokół kościoła Bożej Mądrości w Konstantynopolu i w wielkich klasztorach cesarstwa wschodniego (np. Góra Atos), a ostateczny kształt uzyskał w okresie dynastii Paleologów (1261-1453). Już w drugiej połowie VIII w. liturgia Wielkiego Kościoła rozprzestrzeniła się na kraje słowiańskie,

${ }^{47}$ Por. tamże, s. 356-357.

${ }^{48}$ Por. I. H. Dalmais, The Eastern, s. 34.

${ }^{49}$ Por. B. Varghese, dz. cyt., s. 1.

${ }^{50}$ Por. S. Rosso, dz. cyt., s. 38; X. Koodapuzha, dz. cyt., s. 120. 
inspirując m.in. powstanie pisma i alfabetu zamieszkujących je ludów. Także wspólnoty Patriarchatu Antiocheńskiego (którego liturgia była głównym źródłem tej konstantynopolitańskiej ${ }^{51}$ ) oraz części jerozolimskiego i aleksandryjskiego, które pozostały wierne postanowieniom Soboru Chalcedońskiego (tzw. melchici ${ }^{52}$ ), przed XII w. przyjęły obrządek imperialny, wprowadzając doń niewielkie zmiany ${ }^{53}$.

Sama liturgia, będąc pod wielkim wpływem cesarskiego protokołu wzorowanego na ceremoniale perskim, cechuje się niezwykłym pięknem i wspaniałością, inspirując się przy tym niebiańską liturgią Apokalipsy. Jej pierwotny kształt może być odtworzony na podstawie wielu źródeł, przede wszystkim komentarzy liturgicznych i typikonów. Ze względu na okoliczności historyczne dzisiejsza liturgia bizantyjska odzwierciedla w sobie różne tradycje: konstantynopolitańską (w kwestii celebracji Eucharystii i innych sakramentów), jerozolimską (szczególnie w obrzędach Wielkiego Tygodnia i Bożego Narodzenia) oraz sabaicką (bizantyjska Liturgia Godzin ukształtowała się pod wpływem tradycji przeniesionych przez mnichów z jerozolimskiego klasztoru św. Saby). Dwie pierwsze tradycje zwane są katedralnymi, trzecia zaś - monastyczną ${ }^{54}$.

Liturgia eucharystyczna tradycji bizantyjskiej pierwotnie ukształtowała się prawdopodobnie pod wpływem celebracji kapadockich, których śladem jest sprawowana do dziś Anafora św. Bazylego Wielkiego. Generalnie jednak jest liturgią pochodzenia zachodniosyryjskiego z wieloma elementami jerozolimskimi ${ }^{55}$. Na pochodzenie antiocheńskie wskazują

${ }^{51}$ Por. I. H. Dalmais, Liturgies, s. 54.

${ }^{52}$ Termin wywodzi się z semickiego rdzenia mlk oznaczającego władcę, króla bądź imperatora. Określano nim chrześcijan wiernych chrystologii Soboru Chalcedońskiego, zwołanego przez cesarza bizantyjskiego Marcjana (450-457). Po zerwaniu przez Konstantynopol łączności z Rzymem (1054) pozostali oni przy patriarsze bizantyjskim. Po roku 1724 zaczął istnieć Kościół melchicki zjednoczony z papieżem. Dziś mianem melchitów określa się właśnie katolików obrządku bizantyjskiego należących do patriarchatów w Jerozolimie, Antiochii i Aleksandrii. Por. V. Poggi, Melchita, Chiesa, w: E. G. Farrugia (red.), dz. cyt., s. 484-485; G. O'Collins, E. G. Farrugia, dz. cyt., s. 175.

${ }^{53}$ Por. I. H. Dalmais, The Eastern, s. 36.

${ }^{54}$ Por. S. Rosso, dz. cyt., s. 40.

55 Por. Tamże, s. 149-150; G. Chatziemmanouil, La Divina Liturgia, Cittŕ del Vaticano 2002, s. 9. Warto zauważyć, że Liturgia św. Bazylego sprawowana jest w Kościele bizantyjskim dziesięć razy w roku, w tzw. dni aliturgiczne sprawuje się Liturgię uprzednio poświęconych darów, zaś w pozostałe dni roku codzienną ofiarę eucharystyczną stanowi właśnie Liturgia św. Jana Chryzostoma. Por. J. Klinger, O istocie prawosławia, Warszawa 1983, s. 128. 
też celebracje pozostałych sakramentów, których formuły zestawia Euchologion; wyjątek stanowił tu jedynie sakrament małżeństwa, w którego formie przeważały zwyczaje lokalne. $W$ tekstach teologicznych liturgii szczególny nacisk został położony na epiklezę, w architekturze zaś uderza tajemniczość wyrażona chociażby szczególną obecnością ikon, będących swoistym zobrazowaniem zejścia niebios na ziemię i antycypacją paruzji56.

Liturgia godzin podzielona jest na osiem cykli odpowiadających ośmiu tonom używanym w psalmodii (księga zwana Paraklitiki), cykl wielkopostny (ujęty w księdze Triodion) i wielkanocny (z księgą zwaną Pentekostarion). Charakterystyczne dla omawianej tradycji są tropary, będące krótkimi utworami poetyckimi podsumowującymi znaczenie obchodzonego święta liturgicznego ${ }^{57}$.

Warto zauważyć, że Bizancjum nigdy nie określiło oficjalnej liczby sakramentów świętych (zwanych misteriami). I tak jeden z wielkich formatorów liturgii, Teodor Studyta (†826), wymieniał ich sześć, Mikołaj Kabasilas (†1391) trzy, niektórzy mówią zaś o dziesięciu sakramentach ${ }^{58}$. Jednak zasadniczo przyjmuje się liczbę siedmiu sakramentów ${ }^{59}$.

Niektóre Kościoły tradycji bizantyjskiej posługują się kalendarzem juliańskim inne gregoriańskim. Dla wszystkich jednak początkiem roku jest dzień 1 września ${ }^{60}$.

Nieco inną specyfikę posiada liturgia ormiańska, rozwinięta w kręgu Kościoła odrzucającego postanowienia Chalcedonu. Choć zasadniczy zrąb Eucharystii wywodzi się z modelu jerozolimskiego oraz kapadockiego liturgia nie uniknęła wpływów syryjskich. Stąd obok Anafory św. Bazylego $^{61}$ swoje miejsce znalazła tu także syryjska Anafora św. Jakuba. Uwarunkowania historyczne wystawiły tradycję ormiańską na wiele wpływów, których ślady przetrwały do dziś, toteż oparta na greckich podstawach liturgia, stanowi swoistego rodzaju pomost między zwyczajami Wschodu i Zachodu. Trójpodział celebracji eucharystycznej łączy ją

${ }^{56}$ Por. I. H. Dalmais, Liturgies, s. 53; tenże, The Eastern, s. 37.

${ }^{57}$ Por. Tenże, The Eastern, s. 36; M. Nin, Tropario, w: E. G. Farrugia (red.), dz. cyt., s. 780 .

${ }_{58}$ Por. M. Cunningham, Wiara w świecie bizantyjskim, Warszawa 2006, s. 117.

${ }^{59}$ Por. A. Lorgus, M. Dudko, Orthodoxes Glaubensbuch, Würzburg 2001, s. 96-122.

${ }^{60}$ Por. E. Velkovska, Anno liturgico in Oriente, w: A. J. Chupungco, dz. cyt., t. 5 , s. 193.

${ }^{61}$ Właściwie Kościół ormiański używa tej anafory w jej wersji egipskiej, stąd też często nazywa się ją Anaforą św. Atanazego. Por. I. H. Dalmais, Liturgies, s. 56-57. 
z dziedzictwem chrześcijańskiego Wschodu, jednak elementy takie, jak "ostatnia Ewangelia" według św. Jana upodabnia ją do trydenckiej formy łacińskiej mszy świętej. W celebracjach używa się wszystkich szat greckich i rzymskich, z wyjątkiem zachodnich ornatów. Podczas sprawowania funkcji liturgicznych biskupi używają łacińskiej mitry, pastorału i pierścienia, kapłani zaś nakrywają głowy bizantyjskimi koronami. W Kościele ormiańskim jako jedynym z dawnych Kościołów Wschodu używa do komunii niekwaszonego chleba i nie miesza się wina z wodą. W kwestii sakramentów Ormianie nie różnią się od rzymskich katolików.

Do 1924 r. w Kościele ormiańskim posługiwano się kalendarzem juliańskim, następnie przyjęto gregoriański. Choć znane i praktykowane są tu modlitwy za zmarlych, kanon wiary nie zawiera czyśćca ${ }^{62}$.

Do grupy bizantyjskiej tradycji liturgicznej należą: Autokefaliczne Kościoły Prawosławne (Konstantynopola wraz z sześcioma Kościołami podległymi kanonicznie, Aleksandrii, Antiochii, Jerozolimy, Rosji, Serbii, Rumunii, Bułgarii, Gruzji ${ }^{63}$, Cypru, Polski, Albanii, Czech i Słowacji, Ameryki), Autonomiczne Kościoły Prawosławne (Kościół Góry Synaj, Kościół Finlandii, Kościół Japonii, Kościół Chin, Apostolski Kościół Estonii), Kościoły prawosławne o nietypowym statusie, Kościoły katolickie wywodzące się z prawosławia (Albański, Białoruski, Bułgarski, Chorwacki, Czeski, Grecki, Italo-albański, Macedoński, Melchicki, Neounicki, Rosyjski, Rumuński, Ruteński, Serbski, Słowacki, Ukraiński, Węgierski). Grupę Kościołów wywodzących się z ormiańskiej tradycji liturgicznej stanowią: Ormiański Kościół Apostolski i Ormiański Kościół Katolicki.

\section{LITURGICZNA RODZINA ALEKSANDRYJSKA}

Kościół wspomnianej już wcześniej Aleksandrii, powołujący się na apostolskie pochodzenie od św. Marka, dał początek swojej własnej

${ }^{62}$ Por. A. Atiya, dz. cyt., s. 343-345.

${ }^{63}$ W jednym z opracowań czytamy: „W Iberii (Wschodnia Gruzja - przyp. autora) odprawiano liturgię jerozolimską św. Jakuba początkowo w języku greckim, ale już przed końcem VI w. w języku gruzińskim. W Gruzji Zachodniej stosowano zawsze liturgię bizantyjską, w języku gruzińskim, który w VIII lub IX w. zastąpił język grecki. Gruzja Wschodnia przyjęła liturgię bizantyjską wkrótce po połączeniu się w roku 1008 Gruzji Wschodniej z Zachodnią w jedno królestwo i katolikat". R. G. Roberson, dz. cyt., s. 85 . 
rodzinie liturgicznej. Odrzucenie uchwał Soboru Chalcedońskiego, które w dużej mierze było wyrazem sprzeciwu wobec dominacji bizantyjskiej, doprowadziło w konsekwencji do wyodrębnienia się zupełnie odrębnego Kościoła posiadającego własną tradycję opartą na spuściźnie św. Cyryla Aleksandryjskiego $(† 444)^{64}$.

W porównaniu do liturgicznej rodziny antiocheńskiej, zachowało się niewiele dokumentów poświadczających kształt i tradycje liturgii aleksandryjskiej. Wywodzące się z tego obszaru teksty patrystyczne są bardziej teologiczne niż liturgiczne. Jedynym źródłem na wskroś liturgicznym jest Euchologion Serapiona z Tmuis, (IV w. ( $^{65}$.

\subsection{TRADYCJA KOPTYJSKA I ETIOPSKA}

Nazwa „koptyjski”, która jest synonimem słowa „egipski”, umiejscawia geograficznie pochodzenie omawianej liturgii w delcie Nilu. Sami bowiem Koptowie są potomkami starożytnych Egipcjan, a używany przez nich język liturgiczny stanowi ostatnią fazę ewolucji języka zaświadczanego przez pismo hieroglificzne, hieratyczne i demotyczne. Z faktu przybycia do Egiptu Greków wynika zapoczątkowanie systemu transliteracji w alfabecie greckim, do którego dodano siedem znaków odpowiadających rdzennie egipskim dźwiękom. W skład języka koptyjskiego wchodziły dawne dialekty, wśród których najsłynniejszymi były bohairski, saidzki, fajumski, achmimski i baszmurski. Do dziś w liturgii używany jest dialekt bohairski; ponadto językiem celebracji jest także arabski ${ }^{66}$.

Liturgia koptyjska wyraźnie różni się od omówionych powyżej. Kościół ten bowiem, jako zdecydowany przeciwnik uchwał Chalcedonu, odcinał się od wpływów bizantyjskich. W ogóle z zewnątrz jedynie antychalcedońskie środowisko syryjskie w jakiś sposób oddziaływało na koptyjską wspólnotę, co przełożyło się na reorganizację struktur liturgicznych zgodnie z modelami syryjskimi, usuwając przy tym wiele oryginalnych elementów aleksandryjskich. Jedynie dzięki pewnym elementom obrzędów chrzcielnych oraz strukturze anafory możemy

${ }^{64}$ Por. V. Poggi, dz. cyt., s. 49-51; R. G. Roberson, dz. cyt., s. 29; A. Camplani, Copta, Chiesa Ortodossa, w: E. G. Farrugia (red.), dz. cyt., s. 186-187.

65 Por. M. Nin, Storia, s. 137-138.

${ }^{66}$ Por. A. Atiya, dz. cyt., s. 16-19. 
mieć pojęcie, jak bardzo pierwotna liturgia aleksandryjska różniła się od antiocheńskiej oraz jak wiele analogii łączyło ją z liturgią rzymską ${ }^{67}$. Głównymi reformatorami liturgii koptyjskiej byli patriarchowie: Gabriel II Ibn Turayk (1131-1145) i Gabriel V (1409-1427) ${ }^{68}$.

Liturgia eucharystyczna stanowi u Koptów centralny punkt życia kościelnego. Właściwie wszystkie sakramenty znajdują w niej swój szczyt (dodajmy, że Kościół uznaje siedem sakramentów tożsamych z łacińskimi). Obecnie w Kościele koptyjskim używane są trzy anafory: św. Bazylego Wielkiego, św. Grzegorza z Nazjanzu i św. Marka, spisana i wzbogacona przez św. Cyryla. Użycie tej ostatniej, najbardziej egipskiej w swoim wyrazie, właściwie ogranicza się do liturgii monastycznej. W historii było z pewnością więcej anafor rdzennie koptyjskich: czternaście spośród dzisiaj używanych w Etiopii wskazuje właśnie na egipskie pochodzenie.

Koptyjska Eucharystia skomponowana jest według trójdzielnego modelu: liturgia katechumenów, liturgia wiernych i anafora z komunią i następującym po niej błogosławieństwem przez położenie dłoni na głowie każdego wiernego ${ }^{69}$. Niektórzy uczeni inaczej ujmują ów trójpodział, np. K. Khell mówi o liturgii ofiarowania, liturgii nauczania i liturgii wiernych (anafora) ${ }^{70}$; z kolei N. Liesel wyróżnia następujące elementy koptyjskiej celebracji eucharystycznej: liturgia modlitwy i słowa, liturgia ofiary eucharystycznej i liturgia eucharystycznej uczty ofiarnej ${ }^{71}$. Osobliwością jest przepis, zgodnie z którym ołtarz i naczynia liturgiczne używane przy komunii mogą być użyte tylko jeden raz dziennie ${ }^{72}$.

Kościół koptyjski używa własnego kalendarza (tzw. kalendarz aleksandryjski): do dwunastu trzydziestodniowych miesięcy dodaje się jeszcze kolejny (interkalacja), tzw. „mały miesiąc” (w języku arabskim nazywa się on al-Nasi', „rozszerzenie (czasu)” lub „odroczenie”"73.

Z tradycją Kościoła koptyjskiego łączy się nierozerwalnie Kościół etiopski, który w sprawach dogmatycznych od zawsze wiernie trzymał

${ }^{67}$ Por. I. H. Dalmais, The Eastern, s. 41; J. M. Czerski, dz. cyt., s. 134.

${ }^{68}$ Por. M. Nin, Storia, s. 140-141.

${ }^{69}$ Por. A. Atiya, dz. cyt., s. 126-130; J. Marques de Bute, The Coptic Morning Service for the Lord's Day, London 1908.

${ }^{70}$ Por. K. Khella, Die koptische Liturgie, Hamburg 1989, s. 25.

${ }^{71}$ Por. N. Liesel, Die Liturgie der Ostkirche, Freiburg 1960, s. 31-34.

72 Por. A. Atiya, dz. cyt., s. 128.

${ }^{73}$ Por. A. Cody, Calendar, Coptic, w: A. Atiya (red.), The Coptic encyclopedia, t. 2, New York 1991, s. 433a-436a. 
się nauki aleksandryjskiej. Liturgia etiopska, będąca właściwie córką koptyjskiej rozwiniętą w królestwie Axum, posiada wiele cech oryginalnych, które zrodziły się pod wpływem judaizmu i pogaństwa. Dla przykładu: Etiopczycy obchodzą szabat, praktykują obrzezanie chłopców, unikają wiele potraw, uważanych za nieczyste ${ }^{74}$.

Choć struktura celebracji eucharystycznej jest niemal tożsama z koptyjską, znajdujemy tu wiele subtelnych różnic, szczególnie w obrzędach i modlitwach niewchodzących w skład ordo comunis (śpiewy, błogosławieństwa, modlitwy drugorzędne). Obok wspomnianych już czternastu anafor koptyjskich używa się anafor pochodzenia syryjskiego (wszak pierwsi misjonarze dotarli tam właśnie z Syrii), rodzimego (Anafora Maryi), a nawet krótkiej Anafory Apostołów, zaczerpniętej z Traditio Apostolica św. Hipolita ${ }^{75}$.

Liturgia koptyjska sprawowana jest przez Koptyjski Kościół Prawosławny i Koptyjski Kościół Katolicki, etiopska zaś przez Etiopski Kościół Prawosławny i Etiopski Kościół Katolicki.

\section{ZAKOŃCZENIE}

Rzeczywistość Kościołów, a co za tym idzie także liturgii Wschodnich, wydaje się wciąż nieodkrytą kopalnią wiedzy o tradycjach, formach i sposobach bycia chrześcijanami w najbardziej katolickim, tj. powszechnym znaczeniu. Wydaje się, że $\mathrm{w}$ dobie powrotu ad fontes liturgicos, zapoczątkowanego przez Sobór Watykański II, sięganie do skarbca starożytnych Kościołów, zrodzonych - jak całe chrześcijaństwo - na Wschodzie, jest niezbędnym elementem dotarcia do niezwykle wartościowych, a często zapomnianych elementów. To wszystko bowiem, co zawiera się w tradycji całego Kościoła, stanowi pełną mozaikę chrześcijaństwa, której znajomość pozwoli na odpowiednie umiejscowienie w niej samych siebie.

Celem niniejszego artykułu było przybliżenie polskiemu czytelnikowi struktury liturgicznej chrześcijańskiego Wschodu. Geograficzne umiejscowienie omówionej rzeczywistości połączone z jej historycznymi uwarunkowaniami wydaje się nieodzownym punktem wyjścia w podjęciu dalszych, bardziej szczegółowych badań. Również precyzacja podstawo-

${ }^{74}$ Por. A. Atiya, dz. cyt., s. 136.

${ }^{75}$ Por. I. H. Dalmais, Liturgies, s. 59-60; W. Macomber, Ethiopian liturgy, w: A. Atiya (red.), The Coptic, t. 2, s. 987b-990b. 
wej terminologii (zakres pojęć „Wschód/Orient”, „ryt/obrządek”) jawi się jako konieczne instrumentarium obiektywnej analizy. W powyższym opracowaniu wyłuszczenie tych kwestii pozwoliło na zobiektywizowanie problematyki liturgicznej poszczególnych wspólnot i wyraźne ukazanie specyfiki każdej z nich.

Sam podział rodzin liturgicznych i ujęcie w nich poszczególnych rytów nie był oczywistością. W różnych opracowaniach poszczególne tradycje chrześcijańskiego Wschodu często prezentowane są właśnie jako odrębne rodziny. Jednak wyznaczenie łączących je pierwotnych elementów pozwoliło wskazać dwa ośrodki (Antiochia i Aleksandria), $\mathrm{w}$ których ukształtowały się generalne prawidła rządzące liturgiami wszystkich Kościołów Wschodnich. Z kolei brak osobnego opracowania liturgii jerozolimskiej był zabiegiem zamierzonym: oddziałując poniekąd na inne tradycje i stojąc u początków wszelkich celebracji chrześcijańskich, zostawiła swój ślad niemal w każdym Kościele Wschodu i Zachodu, liturgia jerozolimska była jedynie impulsem do wytworzenia się specyficznych liturgii głównych ośrodków chrześcijańskiego świata.

Na koniec należy dodać, że każde ogólne zestawienie jest narażone na niebezpieczeństwo powierzchowności. Jednak zazwyczaj kreśli ono zarys szerokiej problematyki i może stać się przyczynkiem do dogłębnego studium nieznanych szerzej w polskim środowisku Kościołów.

Abstract.The Liturgical Families of the Eastern Christianity - panorama. The life of the Eastern Churches and their liturgies still remain a deep well of undiscovered riches for many, their fertile and varied traditions are signposts indicating ways of being authentically Christian and truly catholic - in the full universal sense of that word. The return ad fontes liturgicos, called for by the Second Vatican Council, drew deeply from the wisdom of the ancient Churches, which were born - as indeed was the whole of Christianity - "in the East"; the research that was to follow, based on this essential insight, allowed many to reach that desired goal. That sense of dealing with the seamless and undivided garment of the tradition of the whole Church, allowed a complete picture of Christianity to emerge and be presented. The knowledge gained from this research also enabled us to find both an appropriate self understanding for the Christian today and a fuller sense of our Christian faith which draws deeply from its rich and ancient traditions.

In this paper the author has tried to give an outline of Eastern Christianity, firstly the geographical setting and historical foundation of the East/Orient and secondly the oriental meaning and understanding of their use of the term "rite". Such a study allows for a fuller understanding of the two Eastern liturgical families 
(derived from Antioch and Alexandria) and the seven different traditions which flow from them. The general outline given here will hopefully enable a given Polish reader, unfamiliar with this subject, the ability to see the dimensions of the rich liturgical treasure of the Oriental Churches.

Key words: Oriental Liturgies; Liturgy; Eastern Churches; Middle East; tradition 